\title{
Measuring the fiscal governance instruments: a synthetic index for EU countries
}

\author{
Medindo os instrumentos de governança fiscal: \\ um indice sintético para os países da União Europeia
}

\author{
SLAWOMIR FRANEK* \\ MARTA POSTULA**
}

RESUMO: O objetivo do artigo é examinar o efeito coletivo dos instrumentos de governança fiscal (ou seja, regras fiscais, estruturas orçamentárias de médio prazo, instituições fiscais independentes) sobre os resultados fiscais dos estados-membros da UE. Os resultados da estimativa do modelo de dados em painel para 28 países da UE no período 2004-2016 confirmam um impacto estatisticamente significativo e positivo do índice sintético para esses instrumentos na relação entre o saldo das administrações públicas e o PIB. Além disso, foi proposto um ajuste do índice sintético, levando em consideração o grau de autonomia das instituições fiscais independentes e a ligação entre os quadros orçamentários de médio prazo e o orçamento anual.

PALAVRAS-CHAVE: Governança fiscal; regras fiscais; estruturas orçamentárias de médio prazo; instituições fiscais independentes.

ABSTRACT: The aim of the paper is to examine the collective effect of fiscal governance instruments (i.e., fiscal rules, medium-term budgetary frameworks, independent fiscal institutions) on the fiscal outcomes of EU member states. The results of panel data model estimation for $28 \mathrm{EU}$ countries for the period 2004-2016 confirm a statistically significant and positive impact of synthentic index for those instruments on the general government balance to GDP ratio. Additionally, an adjustment of the synthetic index was proposed, taking into account the degree of autonomy of independent fiscal institutions, and the link between medium-term budgetary frameworks and the annual budget.

KEYWORDS: Fiscal governance; fiscal rules; medium-term budgetary frameworks; independent fiscal institutions.

JEL Classification: H61; H50; E62.

\footnotetext{
* Professor of the Szczecin University, Institute of Economics and Finance, Poland. E-mail: slawomir. franek@usz.edu.pl. Orcid: https://orcid.org/0000-0002-9698-4918.

* * Professor Varsaw University, Departament of Finance and Accountability, Faculty of Administration, Poland. E-mail:mpostula@wz.uw.edu.pl. Orcid: https://orcid.org/0000-0001-5502-9722. Submitted: 4/Novembr/2019; Approved: 15/April/2020.
} 


\section{INTRODUCTION}

The need to stabilise fiscal policy in the EU has forced member states to strengthen their fiscal governance instruments. Of key importance among them are fiscal rules, medium-term budgetary frameworks and independent fiscal institutions. For each of those instruments the European Commission developed indicators to measure their strength in respective member states. These are Fiscal Rules Index (FRI), Medium-Term Budgetary Framework Index (MTBF Index) and Scope Index of Fiscal Institutions (SIFI). These indicators are commonly used to measure the relationships between the use of fiscal governance instruments and the fiscal outcomes.

They measure the existence of specific normative solutions rather than their actual effectiveness in the context of the national budgetary process. Despite those limitations, an approach involving numerical indicators is gaining quite a popularity due to their simplicity, even at the cost of some degree of simplification.

Most of the research conducted so far to determine the impact of fiscal governance instruments on the fiscal outcomes deals with respective instruments separately. Only some of the studies point to the need for support from independent fiscal institutions to ensure compliance with fiscal rules (Beetsma et al., 2017; Hallerberg, Strauch and von Hagen, 2007; Wyplosz, 2012). In accordance with those studies, those instruments are complementary to one another and hence it would be legitimate to determine the combined impact of using them in respective countries on the fiscal outcomes. This provides grounds for developing the concept of a synthetic index of the strength of fiscal governance instruments, its value being the resultant of the values of respective component indices. Such an approach draws on the concept of public finance quality measurement put forward by Barrios and Schaechter (2009) and that of quality of budget institutions presented by Gleich (2003).

The aim of the study is to indicate how the fiscal instruments used impact the condition of public finance. An original concept of synthetic index was used for measurement based on the authors' thesis that the same helps demonstrate the overall effect of fiscal rules, independent fiscal institutions and medium-term budgetary frameworks on fiscal outcomes. Our research shows that the significance of medium-term budgetary frameworks should not be overlooked since there is a strong and statistically significant correlation between those instruments and the fiscal output. That's why the synthetic index is structured as an arithmetic mean of FRI, SIFI and MTBF Index.

Research into the relationship between fiscal governance instruments and fiscal output was also conducted using adjusted values of the original indices developed by the European Commission. We concluded that SIFI value should be adjusted by a metric indicating the level of independence of independent fiscal institutions, and the value of MTBF Index should reflect more strongly the links with annual budget. Modification of the SIFI and MTBF Index values and their use in investigating the relationship between the strength of fiscal governance instru- 
ments are and additional argument in favour of the novelty of our research. The research has used data from Fiscal governance database for the period between 2004 and 2016 for European Union member states published by the European Commission. In the analysis of relationships between the strength of fiscal governance instruments and fiscal outcomes panel data model was used.

\section{FISCAL GOVERNANCE INSTRUMENTS VERSUS FISCAL OUTCOMES}

The importance of fiscal governance instruments for stabilising the fiscal policy stems from the fact that strong fiscal rules (Ali Abbas et al., 2011; Frankel and Schreger, 2013) and strong legitimacy of fiscal transparency and of medium-term budgetary frameworks (Beetsma et al., 2011) is conducive to caution in budgetary forecasting. The positive effect of the existence of fiscal rules on ensuring fiscal discipline is attested by papers by Alesina and Bayoumi (1996), Debrun et al., (2008), Tapsoba (2013), among others.

Heinemann et al., (2014) pointed out that fiscal rules may significantly increase financial markets' confidence in countries with a poor reputation. Ayuso-iCasals et al., (2009) report that from 1990 to 2005 an increase in the share of government finances covered by numerical fiscal rules led to lower deficits in the EU countries. A number of studies provide arguments to prove that the introduction of fiscal rules contributes to improved fiscal outcomes, for example: they can contribute to a successful fiscal consolidation (Guichard et al., 2007), deficit or debt rules lead to limiting the budget deficit (Debrun et al., 2008) and to a lower cost of debt servicing (Thornton and Vasilakis, 2018); expenditure rules are conducive to a lower primary expenditure (Deroose, Moulin and Wierts, 2006), also by reducing pressure to increase expenditure in case of revenue windfall (Wierts, 2008). In addition, one can find confirmation that their impact is greater if they are based on strong legal foundations, and compliance with them is strictly enforced (Hallerberg, Strauch and von Hagen, 2007). Badinger and Reuter (2017) also found out, based on data from 74 countries from the years between 1985 and 2012, that countries with more rigorous fiscal rules show a better budgetary balance, lower interest rate spread for bonds, and lower GDP volatility. Similar findings have been made with respect to the use of medium-term budgetary framework. Vlaicu et al., (2014) point out, based on examining 120 countries, that by extending the fiscal planning horizon the deficit is reduced by an average of 2 percentage points.

Other studies reveal that an improvement of fiscal parameters is preceded by the adoption of fiscal rules (Caceres, Corbacho and Medina, 2010) and that it is hard to observe an improvement in fiscal performance of the emerging economies which have adopted fiscal rules compared to those where no such rules are in effect. At the same time, it is pointed out that rules may not be effective unless they come with strong political commitment or strong institutions to support the budget-making process (Hallerberg, Strauch and von Hagen, 2007; Wyplosz, 2012).

Meanwhile, it should be noted that even if fiscal rules in a given country are 
not complied with, upon their introduction, fiscal parameters may be seen to change along the lines of the limitation imposed by a rule. Research by Reuter (2015) conducted on a group of $11 \mathrm{EU}$ countries between 1992 and 2014 reveals that only in half of the years the countries where the rules were in place could boast compliance with them. This means that rules represent a sort of point of reference for good fiscal policy for the government and the society, irrespective of whether they are actually complied with or not. Moreover, Reuter (2017) indicates that rules that tend to be more often complied with are those relating to resources rather than flows, those based on coalition agreements, and those involving a greater coverage of the general government sector.

Many a publication also indicates that fiscal rules strengthen the procyclicality of the fiscal policy (Dessuss et al., 2013; Arezki and Ismail, 2013), especially in connection with pressure to limit capital expenditures in times of economic slowdown. The fiscal rule evolution, taking place over the recent years, towards greater flexibility and towards using corrective mechanisms adapted to the current phase of the business cycle, contributes to strengthening the counter-cyclical nature of fiscal rules, as evidenced by the results of research by Bergman and Hutchinson (2015), Bovy et al., (2014) and Guergil et al., (2017). At the same time, it is worth noting that the increasing complexity of fiscal rules, their frequent modifications and numerous exceptions to their applicability are hardly conducive to the transparency of the fiscal policy in place (Bundesbank, 2015).

Nerlich and Reuter (2013) point out that balanced budget rules and rules based on strong legal foundations are particularly effective. Their research reveals that the effectiveness of rules is higher when they are supported by independent fiscal councils. The existence of independent fiscal institutions favours compliance with fiscal rules, especially those relating to balanced budget and expenditure (Beetsma et al., 2017). The positive impact of independent monitoring and of real time warnings issued by independent bodies when there is a risk of non-compliance with fiscal rules is demonstrated by Reuter's research (2017).

Debrun and Kinda (2014) point out that the existence alone of fiscal rules does not ensure a stronger fiscal equilibrium. They also note that some characteristics of fiscal councils significantly contribute to fiscal discipline: independent operation, presence in public debate, mandate to monitor compliance with fiscal rules, taking part in developing official forecasts. Hence it can be concluded that independent fiscal institutions reduce the asymmetry of information between fiscal policymakers and the public opinion.

The importance of the independent fiscal institutions' autonomy is also manifested by the fact that countries with fiscal councils whose independence is guaranteed by law or at the operating level by having an appropriate composition (i.e., involving professional economists and no politicians) are characterised by better fiscal performance measured at the level of primary balance. Though fiscal councils do not have a direct impact on the fiscal policy in place, one can see their effect on decision-makers' reputation-building efforts. This is reflected by better fis- 
cal performance of the countries where fiscal councils have high media presence via publications addressing the public (Debrun and Kinda, 2017).

Hence the prevalent opinion in the subject matter literature that independent fiscal institutions ensure the existence of more realistic fiscal plans in the medium term, and minimise the risk of delay in fiscal consolidation. The outcomes of these activities are also impacted by institutional finance management solutions. In particular, in countries where the ministry of finance is the body delegated to develop budgetary forecasts, one can observe a greater forecasting optimism, while in countries with strong fiscal rules a much greater forecasting caution is visible. At the same time Ali Abbas (2013) emphasises that independent fiscal institutions are not a panacea to cure the excessive optimism of forecasts amid uncertainty as to shortterm prospects for economic growth and fiscal parameters.

Beetsma et al., (2017) emphasise independent fiscal institutions' sensitivity to political circumstances. Therefore, strict guarantees of independence, including those with regard to the available financial resources, seem important to safeguard their long-term sustainability. It is for the same reason that adapting fiscal councils' institutional model to the country specificity may increase the likelihood of them being accepted across the political spectrum. Where fiscal councils are established as a result of external pressure, they may be susceptible to political changes or ignored by policymakers and the public.

The empirical analysis suggests that only well-designed fiscal councils involve stronger fiscal performance as well as more accurate and less biased forecasts (Debrun and Kinda, 2017). The authors point out that the most important characteristics of effective fiscal councils are operational independence from politics; the capacity for providing or conducting public assessment of budgetary forecasts; a strong presence in the public debate and a marked role in monitoring fiscal policy rules. Fiscal councils may ensure a greater fiscal discipline by supporting fiscal transparency and stimulating a public debate on fiscal policy.

The differences in the structure of respective fiscal governance instruments warrant the conclusion that their impact on fiscal outcomes is not equal. This means that there are grounds to examine the collective effect of fiscal governance instruments on the fiscal outcomes. Developing a synthetic index of the strength of fiscal governance instruments may be useful in this respect.

Most of the research conducted so far to determine the impact of fiscal governance instruments on the fiscal outcomes deals with respective instruments separately. Only some of the studies point to the need for support from fiscal institutions to ensure compliance with fiscal rules (Beetsma et al., 2017; Hallerberg, Strauch and von Hagen, 2007; Wyplosz, 2012). In accordance with those studies, those instruments are complementary to one another and hence it would be legitimate to determine the combined impact of using them in respective countries on the fiscal outcomes. This provides grounds for developing the concept of a synthetic index of the strength of fiscal governance instruments to examine the collective effect of fiscal governance instruments on the fiscal outcomes. 


\section{MEASURING THE QUALITY OF FISCAL GOVERNANCE INSTRUMENTS - INDIVIDUAL INDICES VS SYNTHETIC INDEX}

The complexity of contemporary fiscal governance instruments is reflected by the methods for measuring their quality. Indices published by the European Commission are used to assess the significance of fiscal rules, independent fiscal institutions and medium-term budgetary frameworks. These are Fiscal Rules Index (FRI), Medium-Term Budgetary Framework Index (MTBF Index) and Scope Index of Fiscal Institutions (SIFI). The structure of those indices is based on questionnaire surveys addressed to respective member states, where the key elements of the structure of fiscal governance instruments are identified.

In the recent years, a major progress, measured with FRI changes, has been observed with respect to the strengthening of fiscal rules in most countries. The exceptions are Sweden, Denmark and Austria, where the strength of fiscal rules has not been significantly enhanced in the last decade or so. These countries, however, have years of experience in using them, dating back to the 1990s, and other institutional fiscal solutions also have a strong position there. According to data for 2016, countries with considerable strength of fiscal rules were Bulgaria and Italy (which was mostly due to them using a number of different rules), while Czech Republic and Croatia were countries where fiscal rules play a minor role in the fiscal policy.

The data published by the European Commission confirm major progress achieved in the recent years when it comes to the strengthening of the multi-annual budget horizon. Particularly notable in this area has been the development of countries such as: Greece, Latvia, Bulgaria, Lithuania, Luxembourg, Cyprus, Ireland and Portugal. According to the data for 2016, countries with high quality of medium-term fiscal frameworks were the United Kingdom, Greece and Spain, while Hungary, Czech Republic and Poland got the lowest rating in this area.

When comparing the changes in the value of FRI and MTBF Index between 2016 and the beginning of public finance crisis in the EU, it can be noted that of the nine EU countries whose public debt in 2008 exceeded $60 \%$ of the GDP, seven have seen, since then, a dramatic growth in importance of fiscal rules or medium-term budgetary frameworks. Only Austria and Belgium have failed to record a major improvement in this area, though it's worth bearing in mind that Belgium is a country where the quality of medium-term budgetary frameworks has been highly praised for years, and Austria has had a long experience in the functioning of independent fiscal institutions. Furthermore, it should be pointed out that the countries that between 2008 and 2016 showed a significant increase of the public debt-to-GDP ratio took efforts to strengthen the role of fiscal instruments (by strengthening fiscal rules, e.g., Ireland and Portugal, creating or reforming fiscal institutions, e.g., Spain and Greece, strengthening medium-term budgetary frameworks, e.g., Cyprus, Greece, Portugal). Only for Slovenia and Croatia no significant progress could be observed in this respect. 
Data for SIFI indicate a strong position of those institutions in Spain and in the United Kingdom, and a weak one in Slovenia. It should be added that, for some countries, low SIFI values (Austria, Belgium, the Netherlands) are a bit misleading as there is more than one entity like that operating in each of those countries, meaning a sort of specialisation in tasks fulfilled by respective fiscal institutions in a given country.

These indices cannot take account of all factors and characteristics underlying the fiscal governance framework. They measure the existence of specific normative solutions rather than their actual effectiveness in the context of the national budgetary process. Despite those limitations, an approach involving numerical indicators is gaining quite a popularity due to their simplicity, even at the cost of some degree of simplification.

Most of the research conducted so far to determine the impact of fiscal governance instruments on the fiscal outcomes deals with respective instruments separately. Only some of the studies point to the need for support from fiscal institutions to ensure compliance with fiscal rules (Beetsma et al., 2017; Hallerberg, Strauch and von Hagen, 2007; Wyplosz, 2012). In accordance with those studies, those instruments are complementary to one another and hence it would be legitimate to determine the combined impact of using them in respective countries on the fiscal outcomes. This provides grounds for developing the concept of a synthetic index of the strength of fiscal governance instruments, its value being the resultant of the values of respective component indices.

FRI, MTBF Index and SIFI compiled and published by the European Commission became the basis for developing a synthetic index. The synthetic index is calculated as an arithmetic mean of respective indices. Similar to the calculation of FRI and MTBF Index, equal weights are used in calculating the mean. This is due to the decision not to differentiate the weights as there are no strong theoretical grounds for that. As is the case of FRI and MTBF, Sutherland's method (2005) is relied on, which uses a set of 10,000 randomly generated weights, based on which 10,000 indices are calculated. Random weights are calculated based on uniform distribution for each subindex within the $[0,1]$ interval, then normalised so that their sum is 1 . The distribution of the synthetic index values reflects the possible range of values, assuming that weights are determined this way for each index component. Considering that weights are determined based on uniform distribution, the median value of the synthetic index is asymptotically equivalent to the indicator calculated using equal weights for synthetic index components, or to the nonweighted arithmetic mean.

Figure 1 presents the distribution of synthetic index values for respective EU countries, reflecting its possible percentile range from 1 to 99 , assuming that weights are randomly generated for each index component. This way outliers are ignored. 
Figure 1: Distribution of values of the synthetic index of the strength of fiscal governance instruments in 2016

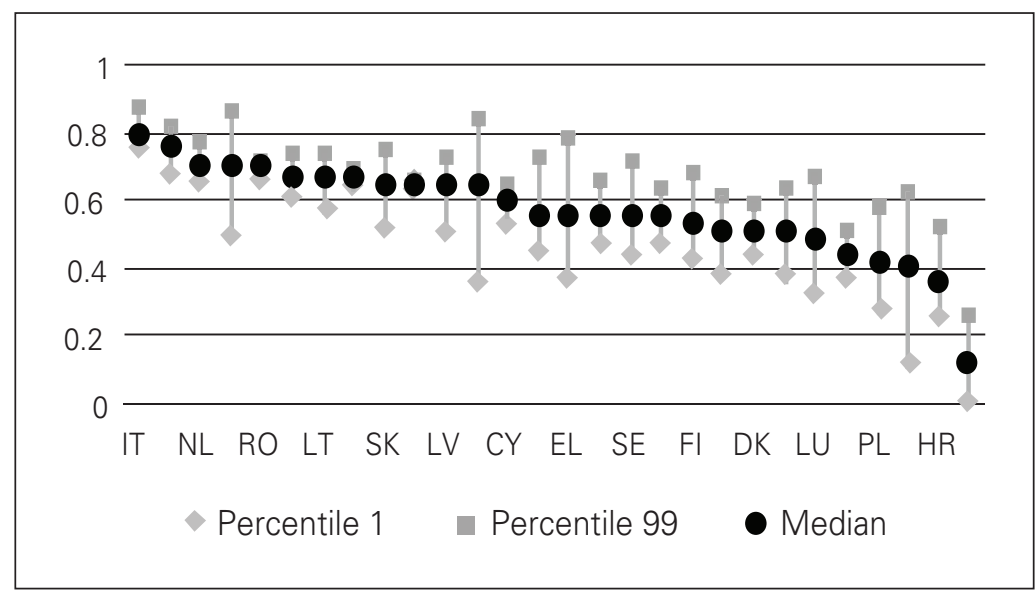

Source: Own calculation

In the period analysed, Czech Republic was the only country not to record an increase in the synthetic index, which attests to the lack of reform leading to greater importance of fiscal instruments. It was not until 2017 that fiscal rules started to be applied in this country. In the other countries, an increase in the strength of fiscal instruments was recorded, measured with the increase of the synthetic index value. In all of the countries, this was due to the FRI value increasing. For MTBF Index, no progress was recorded in eight countries (Czech Republic, Austria, Sweden, Denmark, Slovakia, Belgium, Finland, Croatia), while for the functioning of independent fiscal institutions this was true of six countries (Czech Republic, Austria, Denmark, Belgium, Slovenia, the Netherlands). The fact that Austria, Belgium, Denmark, the Netherlands, Finland, Sweden can be found among countries that have made little progress in enhancing the strength of fiscal instruments means that their fiscal instruments had much earlier reached a significant maturity, and in the period under analysis they would be only making minor adjustments. A major progress can be observed, first and foremost, in the countries that started off from a low base (Romania, Cyprus, Ireland, Portugal, Latvia). Another factor that stimulated the strengthening of fiscal instruments was the fiscal reform implemented in the countries that were experiencing major fiscal tensions in the period under analysis (Ireland, Portugal, Italy, Greece, Spain). Only in a small number of countries does the major increase in the synthetic index value stem from an equal strengthening of each of the instruments analysed (Romania, Cyprus, Portugal, Latvia, France), while other countries focused on selected instruments (Italy, Ireland, Malta, Germany, Slovakia - fiscal rules and independent fiscal institutions, Greece - mediumterm budgetary frameworks and independent fiscal institutions, Spain, the United Kingdom and Estonia - independent fiscal institutions, Luxembourg - mediumterm budgetary frameworks). Such variability in the use of respective fiscal instru- 
ments provides a good case for using a synthetic indicator, the value of which takes account of both the complementary and substitutive nature of the fiscal instruments implemented.

In the group of countries characterised by the highest synthetic index value (i.e., above the third quartile), Italy is the only country where each of the component indices has a high value (i.e., above the third quartile). Hence, only Italy can be said to be characterised by high quality of all fiscal instruments analysed. Meanwhile, it should be pointed out that in all countries with a high synthetic index value, except Bulgaria, the values of component indices are above the median, i.e., at a high or relatively high level (a relatively high value is one that is between the median value and third quartile value). Bulgaria is a country characterised by a large variation in the strength of respective fiscal instruments. Its high position is shaped, most of all, by EU's highest FRI value, though the SIFI value is relatively low (between the first quartile and the median). Hence, it can be pointed out that in the group of countries with high synthetic index value, Spain and the Netherlands show a high strength of medium-term budgetary frameworks, Bulgaria and Lithuania, a high strength of fiscal rules, and Romania and Malta, a high SIFI value.

Another point that needs commenting on is the position of the United Kingdom. Despite high MTBF Index and SIFI values, the synthetic index value is slightly lower due to the low FRI value. The UK and Greece are the only countries with the synthetic value standing below the median, where one of the index components is below the first quartile. This is the case of fiscal rules for both countries.

All countries with a low synthetic index value (below the first quartile) are also characterised by low SIFI values, with Croatia and Czech Republic having low values of each of the component indices.

\section{THE RELATIONSHIP BETWEEN THE STRENGTH OF FISCAL GOVERNANCE INSTRUMENTS AND FISCAL PERFORMANCE - EMPIRICAL RESULTS}

To confirm the hypothesis of the positive impact of fiscal instruments, a model has been built for 28 European Union member states, with the general government balance as the dependent variable, and the following independent variables: FRI, MTBF Index, IFI (dummy variable) equal to 1 for countries with an independent fiscal institution, and 0 when no independent fiscal institution operates in a given country. Control variables in this model are GDP growth, GG debt/GDP and euro (dummy variable) equal to 1 for eurozone member states, and 0 for non-eurozone EU member states. The data used come from Eurostat and from European Commission's databases (fiscal rules database, medium-term budgetary framework database, independent fiscal institutions database). The same explanatory variables are used in the model for the dependent variable that is cyclically adjusted general government balance. The research period is 2004-2016. The panel data model with 
random effects (RE) was used. The choice of the model with random effects was determined by the results of the Mundlak's test (Table 1).

Table 1: Relationship between the strength of fiscal governance instruments and the general government balance

\begin{tabular}{|c|c|c|c|c|c|c|}
\hline \multirow{2}{*}{ Variables } & \multicolumn{3}{|c|}{$\begin{array}{l}\text { General government } \\
\text { balance/GDP }\end{array}$} & \multicolumn{3}{|c|}{$\begin{array}{l}\text { Cyclically adjusted general } \\
\text { government balance/GDP }\end{array}$} \\
\hline & (1) & (2) & (3) & (4) & (5) & (6) \\
\hline GDP growth & $\begin{array}{l}0.31551 * * * \\
(0.03849)\end{array}$ & $\begin{array}{l}0.30998 * * * \\
(0.036670)\end{array}$ & $\begin{array}{l}0.3084 * * * \\
(0.03821)\end{array}$ & $\begin{array}{l}0.07957^{* *} \\
(0.034272)\end{array}$ & $\begin{array}{l}0.07098^{* *} \\
(0.03207)\end{array}$ & $\begin{array}{l}0.06923^{* *} \\
(0.03352)\end{array}$ \\
\hline GGdebt/GDP & $\begin{array}{c}-0.0604 * * * \\
(0.01696)\end{array}$ & $\begin{array}{l}-0.05999 * * * \\
(0.0171)\end{array}$ & $\begin{array}{l}-0.0614 * * * \\
(0.01837)\end{array}$ & $\begin{array}{l}-0.03168^{*} \\
(0.01672)\end{array}$ & $\begin{array}{l}-0.03185^{*} \\
(0.01707)\end{array}$ & $\begin{array}{l}-0.03201^{*} \\
(0.01853)\end{array}$ \\
\hline $\begin{array}{l}\text { Euro (dum- } \\
\text { my) }\end{array}$ & $\begin{array}{l}0.18678 \\
(0.50601)\end{array}$ & $\begin{array}{l}0.30280 \\
(0.51736)\end{array}$ & $\begin{array}{c}0.23442 \\
(0.52482)\end{array}$ & $\begin{array}{l}-0.22330 \\
(0.56181)\end{array}$ & $\begin{array}{r}-0.07105 \\
(0.5684)\end{array}$ & $\begin{array}{l}-0.14942 \\
(0.57075)\end{array}$ \\
\hline FRI & $\begin{array}{l}2.26518^{* *} \\
(1.0767)\end{array}$ & & & $\begin{array}{c}2.71139 * * * \\
(0.98938)\end{array}$ & & \\
\hline IFI (dummy) & $\begin{array}{c}0.77247 \\
(0.57978)\end{array}$ & & & $\begin{array}{l}0.93435^{*} \\
(0.49584)\end{array}$ & & \\
\hline MTBF & $\begin{array}{l}3.67633^{* *} \\
(1.69248)\end{array}$ & & & $\begin{array}{l}4.94351 * * \\
(2.05407)\end{array}$ & & \\
\hline SyntInd1 & & $\begin{array}{l}4.80579 * * * \\
(1.09251)\end{array}$ & & & $\begin{array}{c}6.07065^{* * *} \\
(1.18371)\end{array}$ & \\
\hline Syntlnd2 & & & $\begin{array}{l}6.65057^{* * *} \\
(1.57514)\end{array}$ & & & $\begin{array}{l}8.36654^{* * *} \\
(1.64647)\end{array}$ \\
\hline Const & $\begin{array}{c}-3.1024 * * * \\
(0.94168)\end{array}$ & $\begin{array}{c}-2.17360 * * * \\
(0.74745)\end{array}$ & $\begin{array}{l}-2.3890 * * * \\
(0.77014)\end{array}$ & $\begin{array}{l}-4.71687^{* * *} \\
(1.17007)\end{array}$ & $\begin{array}{c}-3.4003^{* * *} \\
(0.85262)\end{array}$ & $\begin{array}{c}-3.7565^{* * *} \\
(0.90197)\end{array}$ \\
\hline $\mathrm{FE} / \mathrm{RE}$ & $\mathrm{RE}$ & RE & $\mathrm{RE}$ & $\mathrm{RE}$ & $\mathrm{RE}$ & RE \\
\hline $\mathrm{R} \wedge 2$ & 0.3568 & 0.3611 & 0.3467 & 0.1985 & 0.2513 & 0.2334 \\
\hline $\begin{array}{l}\text { Number of } \\
\text { observations }\end{array}$ & 364 & 364 & 364 & 364 & 364 & 364 \\
\hline
\end{tabular}

Robust standard error in parentheses, ${ }^{* *} p<0.01,{ }^{* *} p<0.05,{ }^{*} p<0.1$.

Source: Own calculation.

A number of conclusions can be drawn from specifications estimated as above. Firstly, GDP growth and the GG debt to GDP show a correlation that corresponds to the theory (i.e., a higher economic growth involves a better fiscal balance, and a higher public debt contributes to fiscal balance deterioration). Furthermore, these parameters show statistical significance (though at varying levels depending on the model specification). Secondly, in no model specification did eurozone membership 
prove to be a statistically significant variable having an impact on the fiscal balance, which may be seen as a reflection of the heterogeneity of the eurozone fiscal policy. Thirdly, irrespective of the type of response variable, one can observe a statistically significant and positive impact of using fiscal instruments on the fiscal outcomes. Fourthly, the use of multi-annual budgetary frameworks has the strongest effect on the fiscal balance, while the relationship between fiscal rules and independent fiscal institutions, on the one hand, and the fiscal outcomes, on the other, is noticeably less strong. Specifications (1) and (4) include disaggregated variables related to the strength of respective fiscal governance instruments, whereas synthetic indices were used in all the others. In specifications (2) and (5), a binary value $(0,1)$ indicating the existence of independent fiscal institutions is used to calculate the synthetic index (SyntInd1), in addition to FRI and MTBF Index. In specifications (3) and (5), SIFI rather than binary variable is used to calculate the synthetic index (SyntInd2). Irrespective of the solution adopted, indices structured this way prove to be statistically significant variables. This warrants the conclusion that respective fiscal governance instruments jointly provide a solid ground for improving fiscal stability. At the same time, differences in parameter values between variables SyntInd 1 and SyntInd 2 indicated that what impacts the fiscal outcomes is not only the existence of independent fiscal institutions alone, so does their structure in respective countries.

\section{ADJUSTMENTS TO THE VALUES OF SYNTHETIC INDEX OF THE STRENGTH OF FISCAL GOVERNANCE INSTRUMENTS}

The synthetic index structured based on the published FRI, MTBF Index and SIFI does not fully reflect the strength of respective fiscal instruments. Those indices measure the existence of relevant normative solutions rather than their actual effectiveness in the context of the national budgetary process. Hence the attempt to adjust the component indices relating to independent fiscal institutions and medium-term budgetary frameworks. For FRI, it was concluded that its structure is already so complex that further modifications could restrict the transparency of this index.

It was decided that it is the degree of independence of independent fiscal institutions that determines how strong their effect is on the fiscal policy (Franek, 2015; von Trapp and Nicol, 2018). Taking account of the characteristics of those institutions collected in the independent fiscal institution database published by the European Commission, it is possible to measure the degree of independence of those institutions. The concept of independence of those institutions can be presented following the example of the concept of independence of central banks (Issing, 2006), where areas such as functional, institutional, personal and financial independence can be distinguished. 
Table 2: Criteria of fiscal council independence (INIFI)

\begin{tabular}{|c|c|c|}
\hline № & Criterion name & Assessment scale for the criterion \\
\hline 1. & $\begin{array}{l}\text { Interactions with the } \\
\text { government during the } \\
\text { budgetary process }\end{array}$ & $\begin{array}{l}\text { The government is obligated to consult with the council }-1 \text {, } \\
\text { The government may consult with the council }-0.5 \text {, } \\
\text { No custom of the government consulting with the council }-0\end{array}$ \\
\hline 2. & $\begin{array}{l}\text { Interactions with the } \\
\text { parliament during the } \\
\text { budgetary process }\end{array}$ & $\begin{array}{l}\text { The parliament is obligated to consult with the council }-1 \text {, } \\
\text { The parliament may consult with the council }-0.5 \text {, } \\
\text { No custom of the parliament consulting with the council - } 0\end{array}$ \\
\hline 3. & $\begin{array}{l}\text { Government reaction to } \\
\text { fiscal council forecasts }\end{array}$ & $\begin{array}{l}\text { There is a legal obligation to use council forecasts }-1 \\
\text { Custom dictates the use of council forecasts }-0.67 \\
\text { The government uses its own forecasts, but is obligated to } \\
\text { justify any deviation from forecasts published by the council } \\
-0.33 \\
\text { The government is completely free to use its own } \\
\text { forecasts }-0\end{array}$ \\
\hline 4. & $\begin{array}{l}\text { Presence of politicians } \\
\text { or civil servants among } \\
\text { members of the fiscal } \\
\text { council }\end{array}$ & $\begin{array}{l}\text { No politicians or civil servants }-1 \\
\text { No politicians }-0.5 \\
\text { Politicians present }-0\end{array}$ \\
\hline 5. & Appointment procedure & $\begin{array}{l}\text { No participation of the government or parliament }-1 \\
\text { No participation of the government }-0.5 \\
\text { Government participation }-0\end{array}$ \\
\hline 6. & $\begin{array}{l}\text { Apolitical nature of } \\
\text { members }\end{array}$ & $\begin{array}{l}\text { Yes }-1 \\
\text { No }-0\end{array}$ \\
\hline 7. & Length of term in office & $\begin{array}{l}\text { More than five years - } 1 \\
\text { Up to five years }-0\end{array}$ \\
\hline 8. & Institutional status & $\begin{array}{l}\text { Outside government or parliamentary structures }-1 \\
\text { Within parliamentary structures }-0.5 \\
\text { A part of the government }-0\end{array}$ \\
\hline 9. & Sources of financing & $\begin{array}{l}\text { Nongovernmental - } 1 \\
\text { Governmental - } 0\end{array}$ \\
\hline 10. & $\begin{array}{l}\text { Access to information } \\
\text { available to the government }\end{array}$ & $\begin{array}{l}\text { Full }-1 \\
\text { Privileged }-0.5 \\
\text { No privileges }-0\end{array}$ \\
\hline
\end{tabular}

Source: Own compilation.

For the purposes of this paper, an index of independence of independent fiscal institutions (INIFI) has been created, calculated based on ten criteria of independence. Among these, one can identify criteria of institutional independence, which determine the relations of those institutions with other state authorities that shape the fiscal policy, i.e., government and parliament (criteria no.: 1, 2, 3, 8, 10), those of personal independence which determine the duration of the term in office and lack of political affiliation of the governing bodies of the independent fiscal institution's members (criteria no. 4, 5, 6, 7), and financial independence determining 
the degree of autonomy in managing the institutions' disposable funds (criterion no. 9). The method for assessing compliance with each of the criteria is presented in Table 2. The INIFI value is a mean value of a given institution's point scores for each criterion. In addition, it's worth noting that it is the SIFI value that reflects the functional independence that determines the freedom to choose the way independent fiscal institution's tasks are performed.

Table 3: SIFI, INIFI and adjusted SIFI for independent fiscal institutions in EU countries in 2016

\begin{tabular}{|c|c|c|c|c|c|c|}
\hline Country/Name & SIFI & Rank & INIFI & Rank & $\begin{array}{c}\text { Adjusted SIFI } \\
\text { (average SIFI } \\
\text { and INIFI) }\end{array}$ & Rank \\
\hline ES-AIReF & 0.764 & 2 & 0.850 & 1 & 0.807 & 1 \\
\hline IT-UPB & 0.743 & 3 & 0.650 & 4 & 0.696 & 2 \\
\hline CY-FC & 0.618 & 9 & 0.750 & 2 & 0.684 & 3 \\
\hline $\mathrm{RO}-\mathrm{FC}$ & 0.693 & 4 & 0.648 & 6 & 0.670 & 4 \\
\hline MT-FAC & 0.657 & 6 & 0.634 & 7 & 0.646 & 5 \\
\hline AT-FISK & 0.636 & 7 & 0.600 & 8 & 0.618 & 6 \\
\hline LV-FDC & 0.450 & 15 & 0.750 & 2 & 0.600 & 7 \\
\hline PT-CFP & 0.664 & 5 & 0.500 & 17 & 0.582 & 8 \\
\hline IE-IFAC & 0.632 & 8 & 0.516 & 15 & 0.574 & 9 \\
\hline UK-OBR & 0.771 & 1 & 0.367 & 23 & 0.569 & 10 \\
\hline NL-CPB & 0.614 & 10 & 0.501 & 16 & 0.558 & 11 \\
\hline FR-HCFP & 0.464 & 14 & 0.600 & 8 & 0.532 & 12 \\
\hline SK-CBR & 0.446 & 16 & 0.600 & 8 & 0.523 & 13 \\
\hline $\mathrm{HU}-\mathrm{FC}$ & 0.364 & 22 & 0.650 & 4 & 0.507 & 14 \\
\hline DK-DORS & 0.413 & 20 & 0.567 & 11 & 0.490 & 15 \\
\hline EL-FC & 0.514 & 11 & 0.433 & 21 & 0.474 & 16 \\
\hline LT-NAO & 0.507 & 13 & 0.416 & 22 & 0.462 & 17 \\
\hline FI-NAO & 0.375 & 21 & 0.500 & 17 & 0.438 & 18 \\
\hline$B G-F C$ & 0.414 & 19 & 0.445 & 20 & 0.430 & 19 \\
\hline $\mathrm{EE}-\mathrm{FC}$ & 0.514 & 11 & 0.333 & 24 & 0.424 & 20 \\
\hline LU-CNFP & 0.263 & 24 & 0.533 & 14 & 0.398 & 21 \\
\hline SI-IMAD & 0.200 & 26 & 0.567 & 11 & 0.384 & 22 \\
\hline PL-SAO & 0.200 & 26 & 0.550 & 13 & 0.375 & 23 \\
\hline SE-FPC & 0.429 & 17 & 0.317 & 25 & 0.373 & 24 \\
\hline DE-BEIR & 0.420 & 18 & 0.300 & 26 & 0.360 & 25 \\
\hline HR-CFP & 0.250 & 25 & 0.450 & 19 & 0.350 & 26 \\
\hline BE-HCF & 0.300 & 23 & 0.284 & 27 & 0.292 & 27 \\
\hline$C Z$ & 0.000 & 28 & 0.000 & 28 & 0.000 & 28 \\
\hline
\end{tabular}

Sources: Own compilation.. 
Such an approach underlies the assumption that only when combined can the criteria composing SIFI and INIFI values fully show the "strength" of independent fiscal institutions in shaping and assessing the fiscal policy. That is why the authors of this paper point out that a metric that also takes account of the degree of independence of independent fiscal institutions is one that reflects the position of independent fiscal institutions better than SIFI. This metric is determined as the adjusted SIFI enabling an assessment of the "strength" of the effect of independent fiscal institutions' operations on the shape of fiscal policy. Hence, the adjusted IFI is calculated as the arithmetic mean of SIFI and INIFI. Table 3 presents the values of SIFI, INIFI and adjusted SIFI in 2016 calculated for independent fiscal institutions in EU countries, indicating each institution's ranking position, based on the value of respective indices.

For MTBF Index, it was concluded that the key element of its structure is the criterion of its links to the annual budget. Therefore, it was assumed that the significance of this criterion in shaping the strength of medium-term budgetary frameworks needs to be strengthened. Consequently, as a first step, from the total value of MTBF Index published by the European Commission, its part (determining $1 / 5$ of the MTBF Index value) related to the annual budget was isolated. This way, what is referred to as "raw" MTBF Index value (i.e., without this isolated criterion of links MTBF to the annual budget) was obtained. Next, when determining the value of the adjusted MTBF, the importance of the criterion indicating the link between MTBF and the annual budget has been strengthened. This was done in such a way that the adjusted MTBF Index was calculated as the average value of the "raw" MTBF Index and the index value indicating the relationship between MTBF and the annual budget (which for the purposes of comparability of data is normalized to the range $[0,1])$. In this way, the criterion of MTBF links with the annual budget was increased from 0.2 (in MTBF Index) to 0.5 (in adjusted MTBF Index). Table 4 presents the values of the "raw" MTBF, the index indicating the link between MTBF and the annual budget, and the adjusted MTBF Index, indicating their respective rank. 
Table 4: Adjusted MTBF Index and its components in European Union countries in 2016

\begin{tabular}{|c|c|c|c|c|c|c|}
\hline $\begin{array}{l}\text { Coun- } \\
\text { try }\end{array}$ & $\begin{array}{l}\text { "Raw" } \\
\text { MTBF } \\
\text { Index }\end{array}$ & Rank & $\begin{array}{l}\text { Index of the link } \\
\text { between MTBF and } \\
\text { the annual budget }\end{array}$ & Rank & $\begin{array}{c}\text { Adjusted } \\
\text { MTBF Index }\end{array}$ & Rank \\
\hline UK & 0.707 & 6 & 1.000 & 1 & 0.853 & 1 \\
\hline ES & 0.667 & 8 & 1.000 & 1 & 0.833 & 2 \\
\hline $\mathrm{NL}$ & 0.640 & 13 & 1.000 & 1 & 0.820 & 3 \\
\hline SE & 0.640 & 13 & 1.000 & 1 & 0.820 & 3 \\
\hline $\mathrm{FI}$ & 0.587 & 19 & 1.000 & 1 & 0.793 & 5 \\
\hline CY & 0.533 & 23 & 1.000 & 1 & 0.767 & 6 \\
\hline DK & 0.493 & 24 & 1.000 & 1 & 0.747 & 7 \\
\hline EL & 0.737 & 4 & 0.750 & 8 & 0.743 & 8 \\
\hline EE & 0.567 & 21 & 0.750 & 8 & 0.658 & 9 \\
\hline$B G$ & 0.660 & 11 & 0.500 & 10 & 0.580 & 10 \\
\hline RO & 0.645 & 12 & 0.500 & 10 & 0.573 & 11 \\
\hline $\mathrm{FR}$ & 0.630 & 16 & 0.500 & 10 & 0.565 & 12 \\
\hline BE & 0.615 & 17 & 0.500 & 10 & 0.558 & 13 \\
\hline AT & 0.540 & 22 & 0.500 & 10 & 0.520 & 14 \\
\hline IT & 0.744 & 3 & 0.250 & 15 & 0.497 & 15 \\
\hline MT & 0.728 & 5 & 0.250 & 15 & 0.489 & 16 \\
\hline LT & 0.697 & 8 & 0.250 & 15 & 0.473 & 17 \\
\hline LU & 0.697 & 8 & 0.250 & 15 & 0.473 & 17 \\
\hline IE & 0.633 & 15 & 0.250 & 15 & 0.442 & 19 \\
\hline PT & 0.586 & 20 & 0.250 & 15 & 0.418 & 20 \\
\hline $\mathrm{HU}$ & 0.428 & 27 & 0.250 & 15 & 0.339 & 21 \\
\hline $\mathrm{CZ}$ & 0.317 & 28 & 0.250 & 15 & 0.283 & 22 \\
\hline LV & 0.750 & 1 & 0.000 & 23 & 0.375 & 23 \\
\hline SK & 0.750 & 1 & 0.000 & 23 & 0.375 & 23 \\
\hline SI & 0.700 & 7 & 0.000 & 23 & 0.350 & 25 \\
\hline $\mathrm{HR}$ & 0.600 & 18 & 0.000 & 23 & 0.300 & 26 \\
\hline $\mathrm{DE}$ & 0.483 & 25 & 0.000 & 23 & 0.242 & 27 \\
\hline PL & 0.433 & 26 & 0.000 & 23 & 0.217 & 28 \\
\hline
\end{tabular}

Source: Own compilation. 


\section{THE IMPACT OF THE ADJUSTED SYNTHETIC INDEX ON THE FISCAL OUTCOMES}

Based on the values of IFI, adjusted MTBF Index and FRI, an adjusted synthetic index of the strength of fiscal instruments was built. Its value was calculated, like before, as the arithmetic mean of respective component indices while relying on Sutherland's method (2005). Thus Figure 2 presents the distribution of the adjusted synthetic index values reflecting its possible percentile range from 1 to 99 , assuming that weights are randomly generated for each index component.

Figure 2: Distribution of values of the adjusted synthetic index of the strength of fiscal governance instruments in 2016

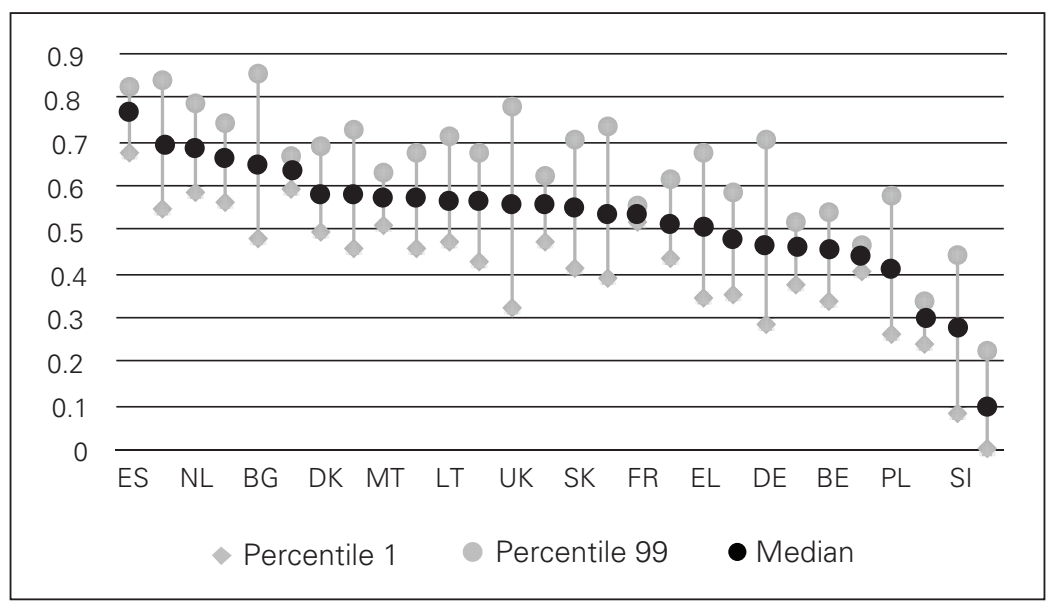

Source: Own compilation.

The adjustment of synthetic index to reflect the stronger effect of the link between MTBF and the annual budget on its values, and greater significance of the independence of fiscal institutions improved synthetic index values of a small group of countries (Denmark, Cyprus, Finland, Spain, Slovenia, Hungary) and put Denmark, Cyprus and Finland in the group of countries where the synthetic index value is above the third quartile. Each of the three countries achieved higher values of component indices for MTBF and SIFI, while the improvement of the synthetic index for Spain and Hungary was due to the positive impact of the adjustment on SIFI, and for Slovenia, by the positive impact of the adjustment on the MTBF Index. Denmark was the only country to be promoted, owing to the adjustments, from the group of countries with relatively low synthetic index value to the group of countries with the highest index value. Countries for which the adjustment caused the greatest decrease in the synthetic index value are Germany, Lithuania and Italy, which, for Lithuania (and Malta, too), meant the country's position falling from being classified to the group of countries with high synthetic index value to the group of countries with a relatively high synthetic index value (with adjust- 
ed index value above the median, but below the third quartile). Also Greece and Slovakia were "relegated" to a lower group (from the group of countries with a relatively high synthetic index value to the group of countries with a relatively low synthetic index value). The adjusted synthetic index value being lower than the one for non-adjusted index stemmed, in most countries, from both MTBF Index and SIFI going down as a result of the adjustments. Bulgaria, Croatia, France, Lithuania, the Netherlands, Poland and Slovakia are countries where adjustments caused the synthetic index values to be lowered due to the low value of the link between MTBF and the annual budget, though in those countries the independence of fiscal institutions has a positive impact on the synthetic index value. The only country where, despite the positive impact of the link between MTBF and the annual budget, the adjusted synthetic index value went down is Sweden, which is due to a lower rating for the degree of independence of fiscal institutions.

The last stage of the research on the strength of fiscal instruments is an empirical verification of the model indicating the link between adjusted values of the independent fiscal institution index and the MTBF Index, on the one hand, and the fiscal outcomes, on the other. The estimation results for this model are presented in Table 5.

Table 5: Panel regression results for the dependent variable: general government balance to GDP/cyclically adjusted general government balance; independent variable: adjusted synthetic index (SyntIndAdj)

\begin{tabular}{|lcc|}
\hline Variables & $\begin{array}{c}\text { General government } \\
\text { balance/GDP } \\
(1)\end{array}$ & $\begin{array}{c}\text { Cyclically adjusted } \\
\text { general government } \\
\text { balance/GDP } \\
(2)\end{array}$ \\
\hline GDP growth & $0.317493^{* * *}$ & $0.0789435^{* *}(0.0345699)$ \\
GGdebt/GDP & $(0.0381947)$ & $-0.0296377^{*}(0.0177037)$ \\
Euro (dummy) & $-0.0569131^{* * *}$ & 0.0377193 \\
SyntIndAdj & $(0.0172913)$ & $(0.5751342)$ \\
Const. & 0.4019375 & $8.332856^{* * *}$ \\
& $(0.5306721)$ & $(1.731203)$ \\
\hline FE/RE & $6.278915^{* * *}$ & -3.929738 \\
R^2 & $(1.628076)$ & $(0.8919349)$ \\
Number of observations & -2.572363 & $R E$ \\
\hline
\end{tabular}

Robust standard error in parentheses, ${ }^{* *} p<0.01,{ }^{* *} p<0.05,{ }^{*} p<0.1$. Source: Own compilation. 
The significance of the parameter of the variable indicating the adjusted synthetic index value attests to the usability of using the index in this form. Another factor of some relevance is that the correlation between the value of the adjusted synthetic index and the response variable is positive, which indicates a positive link between the strength of the fiscal instruments analysed and the fiscal balance. Furthermore, it should be pointed out that the value of parameters for the variable SyntIndAdj is similar to the value of parameters for the variable SyntInd, which means a similar strength of the correlation between the index values and the budgetary outcomes. The use of a synthetic index as an assessment of the strength of fiscal instruments is superior to the individual indices indicating the strength of individual fiscal instruments in that it enables capturing the possible exchangeability of respective instruments. Such a situation occurs for Germany, where the high value of FRI compensates for the relatively low values of the remaining two indices. Meanwhile, for Sweden the strength of fiscal instruments is mainly determined by the high rank of the medium-term budgetary frameworks, with indices relating to fiscal rules and independent fiscal institutions assuming relatively low values. In turn, the high position of Cyprus is made possible, despite an average FRI value, by a considerable strength of medium-term budgetary frameworks and independent fiscal institutions.

Naturally, these results should be approached with some caution, especially given the arbitrary assumption that respective components of the synthetic index have equal weights, and the assumption of a $50 \%$ weight both for the degree of independence of fiscal institutions when determining IFI, and for the criterion of the link between MTBF and the annual budget when determining the adjusted MTBF Index. After all, it should be noted that the value of parameters for variables indicating respective component indices is different, which may warrant the conclusion that the structure of weights should be determined by the relationships among the values of those parameters. However, since it follows from the model specification that not all variables relating to component indices are statistically significant, such an approach is also subject to imperfection. That is why a solution was adopted where, to illustrate the possible impact of different weights on the value of the synthetic index, Sutherland's method was used.

Taking account of the simplifications indicated, it may be concluded, nevertheless, that by jointly including fiscal instruments such as fiscal rules, mediumterm budgetary frameworks and independent fiscal institutions in the synthetic index, it is possible to measure the strength of their link to the fiscal outcomes. The results provide arguments in favour of an integrated implementation of fiscal instruments to ensure they strengthen the institutional framework of the fiscal policy based on complementarity.

\section{CONCLUSIONS}

The research conducted has demonstrated a considerable variability in respective EU countries' use of fiscal instruments, as reflected by different values of the indices measuring the strength of fiscal rules, medium-term budgetary frameworks and independent fiscal institutions. 
The estimation results for the model indicating a link between using fiscal instruments and the fiscal outcomes point to a statistically significant and positive impact of using those instruments on the general government balance to GDP ratio. Interestingly enough, the use of multi-annual budgetary frameworks has the strongest effect on the fiscal balance, while the realationship between fiscal rules and independent fiscal institutions, on the one hand, and fiscal outcomes, on the other are less strong.

The article's analysis of the links between fiscal instruments and fiscal outcomes takes into consideration the combined strength of using relevant instruments. Hence the suggestion to create a synthetic index that takes account of the strength of fiscal rules, medium-term budgetary frameworks and independent fiscal institutions collectively. In addition, the structure of this index also includes the degree of independence of fiscal institutions, and the criterion of the link between MTBFs and the annual budget has been strengthened. A synthetic index structured this way proves to be statistically significant in a model that indicates its link to the fiscal outcomes. This confirms that respective fiscal governance instruments jointly provide a solid ground for improving fiscal stability. Naturally, these results should be approached with some caution, especially given the arbitrary assumption that respective components of the synthetic index have equal weights, and the assumption of a $50 \%$ weight both for the degree of independence of fiscal institutions when determining IFI, and for the criterion of the link between MTBF and the annual budget when determining the adjusted MTBF Index. Taking account of the simplifications indicated, it may be pointed out, nevertheless, that the results of the research conducted provide arguments in favour of an integrated implementation of fiscal instruments to ensure they strengthen the fiscal framework in European Union countries based on complementarity.

\section{REFERENCES}

Alesina, A.; Bayoumi T. (1996) "The costs: benefits of fiscal rules: evidence from US states.” NBER Working Paper, No. 5614.

Ali Abbas S.M. (2010) "Strategies for Fiscal Consolidation in the Post-Crisis World". Washington: IMF,.

Arezki, R.; Ismail K. (2014) "Boom-Bust Cycle, Asymmetrical Fiscal Response: the Dutch Disease.” Journal of Development Economics, Vol. 101, 256-267.

Ayuso-i-Casals, J., Gonzalez Hern:ez, D., Moulin, L.; Turrini A. (2009) "Beyond the SGP: Features: effects of EU national fiscal rules”, in: Policy instruments for sound fiscal policies. Fiscal rules: institution. Palgrave Macmillan, 204-240.

Badinger, H.; Reuter W. H. (2017) “The case for fiscal rules.” Economic Modelling, Vol. 60, 334-343.

Barrios, S.; Schaechter A. (2009) "Gauging by numbers: A first attempt to measure the quality of public finances in the EU.” European Commission Economic Papers 382.

Beetsma, R., Debrun, X., Fang, X., Kim, Y., Lledó, V., Mbaye, S.; Zhang X. (2018) “Independent Fiscal Councils: Recent Trends: Performance.” IMF Working Paper WP/18/68.

Beetsma, R., Debrun, Z.; Sloof. R. (2017) “The Political Economy of Fiscal Transparency and Independent Fiscal Councils.” IMF Working Paper WP 17/195.

Beetsma, R., Bluhm, B., Giuliodori, M.; Wierts P. (2011) "From First-Release to Ex-Post Fiscal Data: Exploring the Sources of Revision Errors in the EU.” CEPR Discussion Paper, No. DP8413. 
Bergman, U. M.; Hutchison M. (2015) "Economic Stabilization in the Post-Crisis World: Are Fiscal Rules the Answer?” Journal of International Money and Finance, Vol. 52, 82-101.

Bova, E., Carcenac, N.,: Guerguil M. (2014) "Fiscal Rules and the Procyclicality of Fiscal Policy in the Developing World.” IMF Working Papers, No. 14/122.

Bundesbank. (2015) “Zur Entwicklung der öffentlichen Finanzen im Euro-Gebiet.” Monatsbericht, Frankfurt.

Caceres, C., Corbacho, A.; Medina L. (2010) "Structural Breaks in Fiscal Performance: Did Fiscal Responsibility Laws Have Anything to do with Them?” IMF Working Paper, No. 10/248.

Debrun, X.; Kinda T. (2014) "Strengthening post-crisis fiscal credibility-fiscal councils on the rise: A new dataset." IMF Working Paper, No.14/58.

Debrun, X., Moulin, L., Turrini, A., Ayuso i-Casals, J.; Kumar M. (2008) “Tied to the Mast? National Fiscal Rules in the European Union.” Economic Policy, Vol. 23(54), 297-362.

Deroose, S., Moulin, L.;Wierts P. (2006) "National Expenditure Rules: Expenditure Outcomes and Evidence for EU Member States.” Wirtschaftspolitische Blätter, No. 1, 27-41.

Dessus, S., Diaz Sanchez, J. L.; Varoudakis A. (2013) "Fiscal Rules and the Procyclicality of Public Investment in the West African Economic and Monetary Union.” The World Bank Policy Research Working Paper Series, No. 6562.

Franek, S. (2015) “Are Independent Fiscal Institutions Really Independent?” Eurasian Journal of Economics: Finance. Vol. 3(3), 35-44.

Frankel, J.; Schreger. J. (2013) "Over-optimistic official forecasts and fiscal rules in the Eurozone." Review of World Economics, Vol. 149(2), 247-272.

Gleich, H. (2003) "Budget Institutions: Fiscal Performance in Central and Eastern European Countries." ECB Working Paper No. 215.

Guerguil, M., M:on, P.; Tapsoba R. (2017) "Flexible Fiscal Rules: Countercyclical Fiscal Policy.” Journal of Macroeconomics, Vol. 52, 189-220.

Hallerberg, M., Strauch, R.; von Hagen J. (2007) “The Design of Fiscal Rules and Forms of Governance in European Union Countries." European Journal of Political Economy, 23(2), 338-359.

Heinemann, F., Osterloh, S.; Kalb A. (2014) "Sovereign risk premia: The link between fiscal rules and stability culture.” Journal of International Money: Finance, Vol. 41, 110-127.

Issing, O. (2006) "Central Bank Independence - Economic and Political Dimensions." National Institute Economic Review, 196(1), 66-76.

Nerlich, C.; Reuter W. (2013) "The design of national fiscal frameworks and their budgetary Impact." ECB Working Paper, No. 1588.

Poterba, J.M. (2005) "Budget institutions: fiscal policy in the U.S. states." American Economic Review, $86(, 2), 1996,395-400$.

Sutherl:, D., Price R.; Joumard I. (2012) "Fiscal Rules for Sub-Central Governments: Design and Impact.” OECD Working Paper, No. 52.

Tapsoba, R. (2012) "Do National Numerical Fiscal Rules Really Shape Fiscal Behaviours in Developing Countries? A Treatment Effect Evaluation.” Economic Modelling, 29(4), 1356-1369.

Thornton, J.; Vasilakis C. (2018) "Fiscal rules and government borrowing costs: International evidence.” Economic Inquiry, 56(1), 446-459.

von Trapp, L.; Nicol S. (2018) "Measuring IFI independence: A first pass using the OECD IFI database”, in: Independent Fiscal Councils: Watchdogs or lapdogs?, edited by R. Beetsma; X. Debrun. London: CEPR Press.

Wierts, P. (2008) “How do Expenditure Rules affect Fiscal Behaviour?” DNB Working Papers 166, Netherl:s Central Bank.

Wyplosz, C. (2012) "Fiscal Rules: Theoretical Issues and Historical Experiences." NBER Working Paper, No. 17884.

Vlaicu, R., Verhoeven, M., Grigoli, F.; Mills Z. (2014) “Multiyear budgets and fiscal performance: Panel data evidence." Journal of Public Economics, Vol. 111, 79-95. 